\title{
First record of the invasive mosquito species Aedes (Stegomyia) albopictus (Diptera: Culicidae) on the southernmost Mediterranean islands of Italy and Europe
}

\author{
Marco Di Luca ${ }^{1 *}$, Luciano Toma' ${ }^{1}$, Francesco Severini', Daniela Boccolini', Salvatore D’Avola², Diego Todaro², \\ Alessandra Stancanelli ${ }^{3}$, Francesco Antoci ${ }^{3}$, Francesco La Russa ${ }^{3}$, Sandro Casano ${ }^{4}$, Salvatore D. Sotera ${ }^{5}$, \\ Eugenio Carraffa ${ }^{6}$, Veerle Versteirt ${ }^{7}$, Francis Schaffner ${ }^{8,9}$, Roberto Romi $^{1}$ and Alessandra Torina ${ }^{3}$
}

\begin{abstract}
Background: Aedes albopictus, a known worldwide vector of several mosquito-borne disease pathogens including dengue, chikungunya and Zika viruses, was introduced into Europe in the late 1970s through global trade. First recorded in northern Italy in 1990, this mosquito species has rapidly spread throughout the country, where it was responsible for an outbreak of chikungunya in 2007 that affected more than 200 people. As part of the VectorNet project, which is aimed at improving preparedness and responsiveness for animal and human vector-borne diseases in Europe, a mosquito targeted study was carried out on the three southernmost Italian islands. The objective was to verify the current European southern distribution limits of Ae. albopictus and the potential occurrence of other invasive mosquito species, in the light of the introduction of high risk for vector-borne disease pathogens into Europe via migration flows.

Results: In the summer 2015, six surveys for container-breeding mosquitoes were carried out by setting up a network of oviposition traps and BG Sentinel traps in selected areas on the islands of Pantelleria, Lampedusa and Linosa. Aedes albopictus was found on all three islands under investigation. The consequences on public health with regard to the presence of this mosquito vector and the migrant people entering the country from Africa and the Middle East are also discussed here.

Conclusions: The detection of the Asian tiger mosquito on these islands, which represent the last European strip of land facing Africa, has important implications for public health policy and should prompt the national authorities to implement tailored surveillance activities and reinforce plans for preparedness strategies in such contexts.
\end{abstract}

Keywords: Aedes albopictus, First record, Invasive mosquito, Entry routes, Lampedusa, Linosa, Pantelleria, Italy

\section{Background}

Aedes (Stegomyia) albopictus (Skuse, 1894) (Diptera; Culicidae), also known as the Asian tiger mosquito, is recognised as one of the 100 most invasive species in the world [1]. The rapid spread of this species is mainly due to passive dispersion by the global trade of used tyres and ornamental plants (such as Dracaena spp. or

\footnotetext{
* Correspondence: marco.diluca@iss.it

'Department of Infectious Diseases, Unit of Vectorborne Diseases, Istituto

Superiore di Sanità, Rome, Italy

Full list of author information is available at the end of the article
}

"lucky bamboo") or by intracontinental transportation in land vehicles [2-8].

In Europe, after its first detection in Albania in 1979 [9], Ae. albopictus was reported in Genoa, northern Italy, in 1990 [10] and the Veneto Region in the following year [11].The species has rapidly spread throughout the country with scattered foci mainly in inhabited areas where it now represents the prevalent source of mosquito nuisance [12].

Competent in transmitting a large number of arboviruses worldwide [6, 13], Ae. albopictus proved to be responsible for the outbreak of chikungunya (CHIK) fever 
that occurred in Italy in 2007, which was the first in Europe [14]. The species was also reported as a primary vector in isolated cases of dengue (DEN) and CHIK that occurred in France and Croatia on several occasions [15-19]. Recently, Ae. albopictus is also suspected of being involved in Zika (ZIK) virus transmission and its potential as a ZIK virus vector was evaluated in experimental studies with mosquito populations originating from the Americas and Europe [20-22]. In particular, an Italian Ae. albopictus population exhibited a partial competence to this virus [21].

These events have raised deep concern in both health authorities and public opinion about the possibility of autochthonous transmission of arboviruses, especially in those European countries where Ae. albopictus populations are well-established. Given the invasive behaviour of the mosquito species, and its potential role as a vector of pathogens causing human diseases, surveillance and control strategies are pivotal and should be implemented at a national and local level [23].

Therefore, the widespread presence of Ae. albopictus at relevant densities and the high risk of Aedes-borne pathogen transmission in Italy have led to the investigation of its occurrence in extreme environments, such as the small Mediterranean islands south of Sicily that represent the last European strips of land facing Africa. Notably, in recent years the introduction of Ae. albopictus has been documented in other southwestern Mediterranean islands, such as the Balearic Islands [24] and the Maltese Archipelago [25].

In 2014, with the aim of reinforcing the prevention and control of both animal and human vector-borne diseases, and in improving preparedness and responsiveness for these diseases in the European Union (EU), a joint project with the European Food Safety Agency (EFSA) and the European Centre for Disease Prevention and Control (ECDC), called VectorNet, was set up. One of the main objectives of VectorNet is to implement targeted entomological surveillance/ monitoring in Europe and the area surrounding the Mediterranean Basin. In this regard, the Istituto Superiore di Sanità (ISS) of Rome and the Istituto Zooprofilattico Sperimentale della Sicilia (IZS) of Palermo were involved and both institutes carried out an entomological study on the islands of Lampedusa, Linosa and Pantelleria, during the summer of 2015. The study aimed to verify the current southernmost European distribution limits of Ae. albopictus and to investigate the potential occurrence of other invasive mosquito species, in light of the presence on Lampedusa of the first reception centre for migrants arriving there. According to the Italian Ministry of Interior, about 11,500 migrants, originating mainly from Africa, arrived in Italy in 2016.
Here we report the first detection of Ae. albopictus on these islands.

\section{Methods \\ Study area}

The present study was carried out on the three southern minor islands of Sicily, Lampedusa, Linosa and Pantelleria, in 2015 (Fig. 1a). Lampedusa and Linosa (constituting the Pelagie Archipelago along with the uninhabited islet of Lampione), and Pantelleria represent the southernmost Italian and European areas in front of northern Africa. Lampedusa and Lampione belong geologically to the African continent, whereas Linosa and Pantelleria are of volcanic origin.

Lampedusa and Linosa, with a total area of about $26 \mathrm{~km}^{2}$, belong to the Province of Agrigento. Two hundred and five $\mathrm{km}$ off the coast of Sicily, Lampedusa is the largest island of the Pelagie Archipelago and the southernmost area of Italy. It has a coastline of $40 \mathrm{~km}$ and an area of $20.2 \mathrm{~km}^{2}$, extending in length for about $11 \mathrm{~km}$ in a west-east direction. The island has 6000

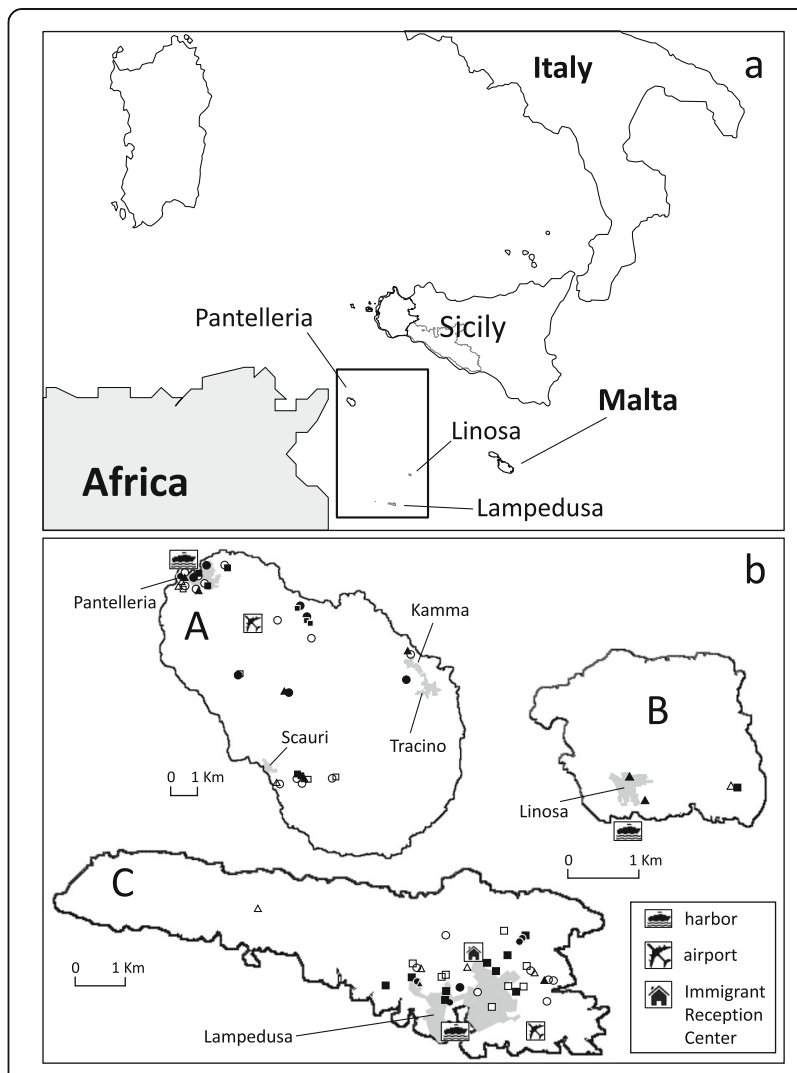

Fig. 1 Map of the study area. a Geographical locations on the islands of Pantelleria (A), Linosa (B) and Lampedusa (C) in the Mediterranean Sea. $\mathbf{b}$ Detail of the three islands showing locations of ovitraps (circle), adult traps and human landing catches (square), and larval breeding sites inspected (triangle) during the entomological field study, July-October 2015. Black dots show the findings positive for Ae. albopictus, white dots, the negatives 
inhabitants, which increases to about 45,000 with the arrival of tourists during the summer season. Lacking rivers and having scarce and intermittent springs, water is supplied almost exclusively from tanks scattered throughout the island by a desalinator facility. Cultivated land generally occupies areas less exposed and more protected from the strong winds, and fields surrounded by dry stone walls or thick hedges of prickly pears are typical on the island. Only three domestic livestock farms are present on the island, two sheep and goat farms and one horse riding stables.

Forty-two km from Lampedusa and $114 \mathrm{~km}$ South-East of Pantelleria, Linosa is $3.4 \mathrm{~km}$ long and $2.7 \mathrm{~km}$ wide, with an area of about $3 \mathrm{~km}^{2}$. This small island (which has about 450 inhabitants) is of recent origin (about 300,000 years old) and represents the emerged part of a volcano which has its base at about $800 \mathrm{~m}$ below sea level. The highest elevation is Monte Vulcano, which is $195 \mathrm{~m}$ a.s.l. Here, the water is available only from tanks.

Pantelleria (which has 7700 inhabitants, increasing to more than 20,000 in summer) belongs to the Province of Trapani and extends for about $80 \mathrm{~km}^{2}$. The island is of volcanic origin and lies $110 \mathrm{~km}$ southwest of Sicily and $70 \mathrm{~km}$ northeast of Tunisia. It has a mountainous terrain, with the highest peak of Montagna Grande (836 m a.s.l.) originating from a volcanic caldera, now covered by woods. There are numerous thermal springs containing silica and sodium carbonate. On Pantelleria there is also a lake of brackish water of volcanic origin, called Specchio di Venere Lake, which contains both meteoric water and thermal spring water $\left(40-50{ }^{\circ} \mathrm{C}\right)$, rich in salt and sulphur compounds. The island lacks sources of drinking water and inhabitants, mainly concentrated in the three villages of Pantelleria, Khamma and Scauri, use water tanks supplied by a desalination plant. The climate is Mediterranean, tempered by sea winds that blow throughout the seasons. The Mediterranean maquis dominates the southeastern part of the island while pine forests grow on the highest peaks, which at lower altitudes are replaced by oak trees; cultivation of vines and olive trees is very common. The horse riding stables is located near the lake; several domestic animal farms (pigs, donkeys, cattle, sheep, goats, poultry), both intensive and household, are scattered on the island, while the only kennel on the island is situated in the village of Pantelleria.

The climate of this Mediterranean area is characterized by a long dry season and a short mild wet season.

\section{Mosquito collections}

In the summer and early autumn of 2015, six surveys were carried out on Lampedusa (6-9th and 14-18th July, 27-30th October), Linosa (28th October) and Pantelleria (12-16th and 19-22th October). The monitoring activities were conducted according to ECDC guidelines
[26], by setting up a network of BG Sentinel ${ }^{\mathrm{Tw}}$ traps (Biogents, Regensburg, Germany) and ovitraps in areas frequented by humans and domestic animals (Fig. 2) and by inspecting a series of artificial containers (removable or non-removable), as potential larval breeding sites (Fig. 3), on the islands. Mosquito collection sites are reported in Fig. 1b. Thirty-three ovitraps were placed on Lampedusa and Pantelleria and checked at the end of each survey (3-4 days) for the presence of mosquito eggs and larvae; all collected strips of Masonite from ovitraps were labelled and left to dry at room temperature. Larval collections were performed using dippers or droppers and larvae gathered were preserved in alcohol. Adult mosquitoes were collected by using BG Sentinel ${ }^{\mathrm{m}}$ traps baited with BG-Lure (Biogents, Regensburg, Germany) on Lampedusa and Pantelleria or were directly aspirated by handheld electric aspirators on vegetation or while landing on exposed skin. The traps worked from sunrise to sunset for 1-3 days and were checked every day. All specimens from traps or from human landing catches were frozen. All samples were then transferred to the laboratories of ISS and IZS for identification. Strips of Masonite were examined under a stereo-microscope, eggs were counted and allowed to hatch for rearing in the insectaries of both institutes. Larval and adult specimens were morphologically identified using the keys of Severini et al. [27], Romi et al. [28] and the interactive CD by Schaffner et al. [29].

\section{Results}

Aedes albopictus was found on all three of the islands investigated; no other potentially invasive species were identified during the surveys.

During the three surveys on Lampedusa, monitoring activity was carried out by 15 BG Sentinel traps and 12 ovitraps, placed in selected sensitive urban and periurban areas of the island, such as shaded verandas and yards of resorts or private dwellings, tyre centres, open green spaces of the hospital, a clinic, the town hall, the Sanctuary of Madonna di Porto Salvo, an isolated place of worship, the airport, the immigrant reception centre, stables and animal shelters (Tables 1 and 2).

In total 62 adults of Ae. albopictus were collected (Table 1). During the inspections of artificial water receptacles (Fig. 3), six larvae were found in flower pots at the cemetery and the sanctuary (Table 3). Several abandoned boats were also inspected in order to find bilge water suitable for the development of native or invasive mosquitoes. At the time of the inspection, these potential breeding sites were found to be dried out.

During the short survey $(6 \mathrm{~h})$ on Linosa, two larvae were found in flower pots in the small cemetery and two larvae and one pupa were found in a plastic container below a house gutter in the village (Table 


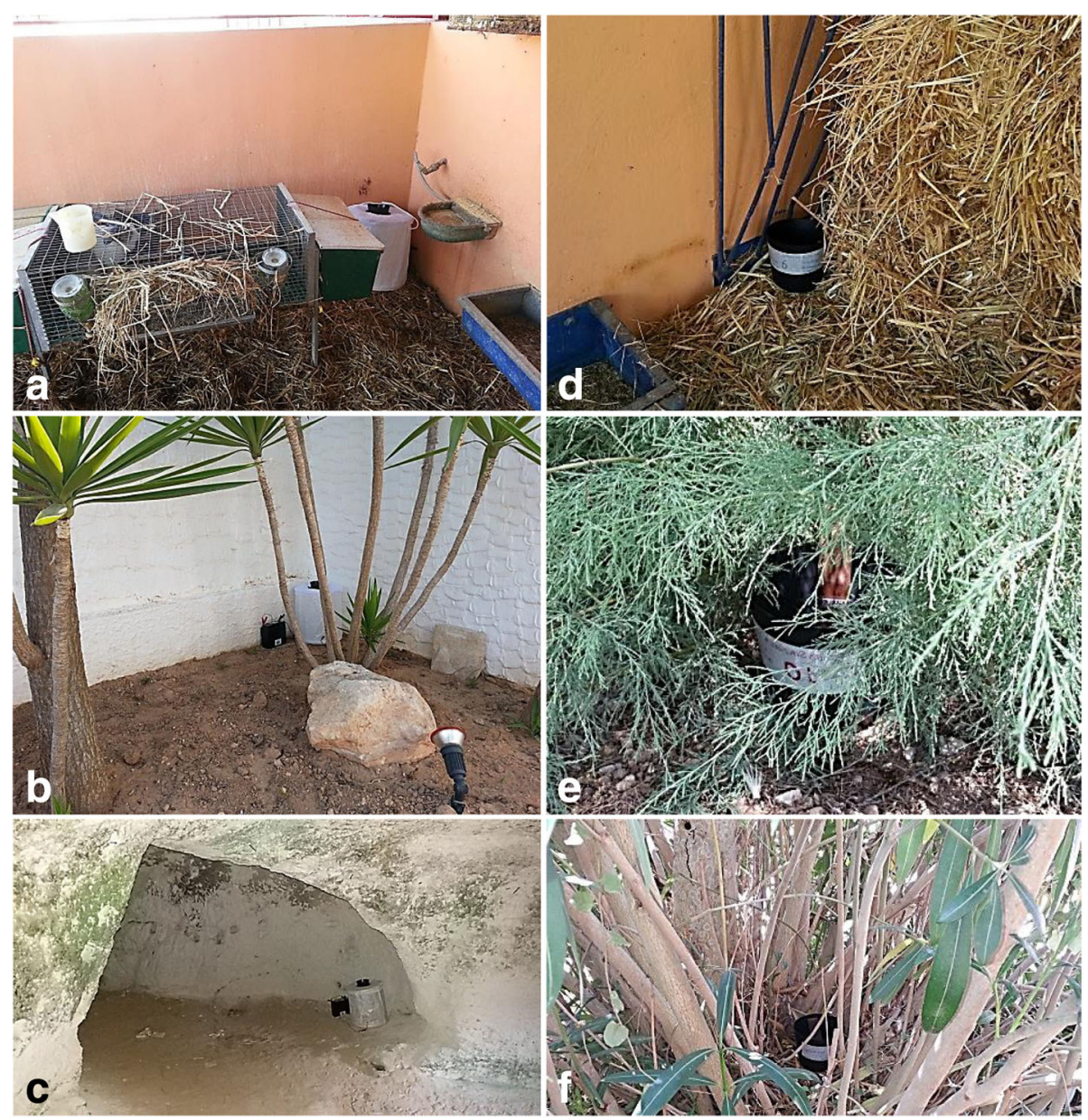

Fig. 2 Examples of traps operating at several mosquito collection sites. Odour-baited adult traps (BG-Sentinel) at: a Costa House Resort (rabbit hutch); b Costa House Resort (dwelling houses); c Sanctuary of Madonna di Porto Salvo (cave). Ovitraps in: d Costa House Resort (stable); e airport (shrub); $\mathbf{f}$ Sanctuary of Madonna di Porto Salvo (garden)

3). In addition, one adult female was collected with an aspirator in the large vegetable garden of a detached house, outside the village (Table 1). No ovitraps or adult traps were placed on the island (Fig. 1b).

Also on Pantelleria a network of traps $(n=8)$ and ovitraps $(n=21)$ was placed at selected sites, such as human dwellings and offices, cemeteries, the hospital, resorts, restaurants, animal shelters, and a kennel (Tables 1 and 2). Aedes albopictus was found (19 adults and over 70 immature mosquitoes) both in urban and rural environments. Of eight breeding sites inspected, five were positive for the species: at two of the three cemeteries on the island, two isolated houses with gardens and domestic animals, and a manhole in the yard of the veterinary office (Table 3). Of note, one adult was caught while landing on human bait near the lake, in a typically natural setting (Table 1). During the two surveys, 8 out of 21 ovitraps were found to be positive (Table 2 and Fig. 1b).

\section{Discussion}

Entomological surveys were carried out on three minor Mediterranean islands south of Sicily, Lampedusa, Pantelleria and Linosa, during the summer of 2015. The aim of these surveys was to verify the presence and, in that case, assess the distribution of potentially invasive mosquito species, including Ae. albopictus, considered as a competent vector of DEN, CHIK and ZIK viruses. At the beginning of 2015, the VectorNet consortium determined this task as a priority for Italy, not only because of data gaps in the known distribution of Ae. albopictus, but also because these areas were identified as high risk for vector-borne pathogen introduction via migration flows. For many years, the southern coasts of Italy have represented the first entrance point for economic migrants and refugees into Europe. The immigrant reception centre of Lampedusa, operating since 1998, represents the primary European entry point for immigrants, mainly from Eritrea, Nigeria, Somalia, Syria, Gambia and Sudan. Although a real risk of transmission 

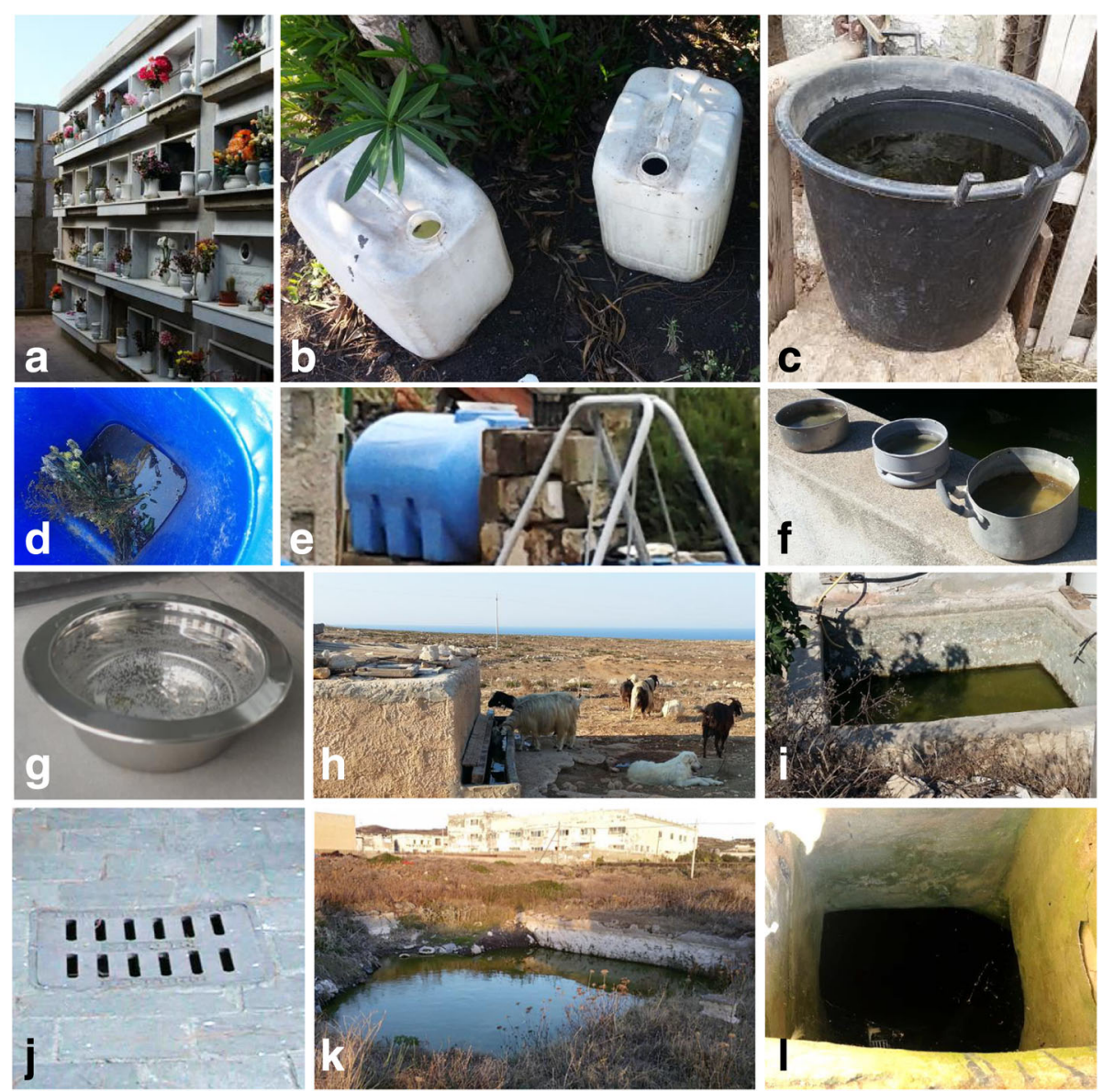

Fig. 3 Examples of artificial larval habitats inspected and listed in Table 3: a flower vases; $\mathbf{b}$ plastic jerry cans; $\mathbf{c}$ bucket; $\mathbf{d}$ bottom of wheelie dustbin; e plastic tank; $\mathbf{f}$ cooking pots; $\mathbf{g}$ dog bowl; $\mathbf{h}$ animal trough; i brick-tank; $\mathbf{j}$ manhole; $\mathbf{k}$ water pit; I well

of vector-borne pathogens exists on Lampedusa, the extreme climatic and environmental conditions and the short period of stay of the migrants (2-15 days) do not favour the triggering of such events. Moreover, recent studies seem to confirm a low vulnerability at this point of entry. From January 2011 to June 2014, about 49,000 migrants arrived on Lampedusa, but hospitalisation was required for only 378 (0.51\%). Among ascertained infectious diseases, mainly respiratory and intestinal distress were reported, while only one case of malaria was detected [30, 31]. Unfortunately, it was impossible to visit the reception centre of Lampedusa, because it operates under military jurisdiction, but the placement of one ovitrap at the entrance of the area was authorized. The site was positive for Ae. albopictus in both the surveys in July (60 eggs in the first week and 7 eggs in the second). Similarly, the airport area was monitored, using one ovitrap which was found positive at both trapping occasions in July (70 and 9 eggs, respectively).

This study represents the first entomological investigation focusing on mosquito fauna in the Pelagie archipelago and on Pantelleria. The recording of Ae. albopictus on these islands is an important finding, demarcating new boundaries of the distribution range of the species in Europe and indicating Lampedusa as its southernmost limit. As in other similar settings [32-34], it is very difficult to speculate when the Tiger mosquito arrived on these three islands; the mosquito had never been reported there before, probably because of the low density of Ae. albopictus populations did not create nuisance for the inhabitants, who did not notice its presence. The maritime route is the most likely pathway, given the high percentage of containers and goods transported by ship and the high number of direct ferries carrying vehicles with tourists from the island of Sicily, where the presence and abundance of Ae. albopictus is welldocumented [35-37]. This mosquito species could have reached Linosa directly from Sicily or from Lampedusa, due to the daily connections with these two islands.

Despite the fact that the extreme environmental conditions (in terms of aridity, strong winds, seasonal lack of water resources, and scarcity of green areas and breeding 
Table 1 Results of Aedes albopictus adult trapping with BG sentinel traps (BG) or handheld electric aspirators (A) on the islands of Lampedusa, Pantelleria and Linosa (July and October 2015)

\begin{tabular}{|c|c|c|c|c|c|c|}
\hline Island & Latitude (N) & Longitude (E) & Method of capture & Sampling area & Sampling period & No. of adults \\
\hline \multirow[t]{24}{*}{ Lampedusa } & 35.50638 & 12.59555 & BG & Cupola Bianca Resort (garden) & 06/07/2015 & 0 \\
\hline & \multirow[t]{2}{*}{35.50417} & \multirow[t]{2}{*}{12.59528} & & \multirow[t]{2}{*}{ Sanctuary of Madonna di Porto Salvo } & 07-09/07/15 & 1 \\
\hline & & & & & $27-30 / 10 / 2015$ & 24 \\
\hline & \multirow[t]{2}{*}{35.50500} & \multirow[t]{2}{*}{12.61765} & & \multirow[t]{2}{*}{ Costa House Resort (rubbit hutches) } & 07-09/07/15 & 0 \\
\hline & & & & & $27-30 / 10 / 2015$ & 0 \\
\hline & \multirow[t]{2}{*}{35.50521} & \multirow[t]{2}{*}{12.61796} & & \multirow[t]{2}{*}{ Costa House Resort (dwelling houses) } & 07-09/07/15 & 0 \\
\hline & & & & & $27-30 / 10 / 2015$ & 0 \\
\hline & 35.50420 & 12.60067 & & Le Anfore Club Resort & $14 / 07 / 2015$ & 0 \\
\hline & 35.50900 & 12.61774 & & Medical Centre & $14 / 07 / 2015$ & 0 \\
\hline & 35.50191 & 12.60136 & & Port Restaurant & $14 / 07 / 2015$ & 9 \\
\hline & 35.49887 & 12.60358 & & Quarta Isola Restaurant & $14 / 07 / 2015$ & 0 \\
\hline & 35.50437 & 12.62027 & & Tyre Centre & $15 / 07 / 2015$ & 0 \\
\hline & 35.50727 & 12.61354 & & Private residence (garden) & $15 / 07 / 2015$ & 7 \\
\hline & 35.51299 & 12.61721 & & Private residence (garden) & $15 / 07 / 2015$ & 0 \\
\hline & 35.50145 & 12.61445 & & Tyre centre & $16 / 07 / 2015$ & 3 \\
\hline & 35.50618 & 12.60974 & & Private residence (garden) & $16 / 07 / 2015$ & 1 \\
\hline & 35.50099 & 12.60067 & & Private residence (garden) & $16 / 07 / 2015$ & 0 \\
\hline & 35.50478 & 12.61113 & & City Hall & $17 / 07 / 2015$ & 2 \\
\hline & 35.51048 & 12.61708 & A & Supermarket forecourt & 06/07/2015 & 2 \\
\hline & 35.50338 & 12.59019 & & Cala Madonna beach & 07/07/2015 & 1 \\
\hline & \multirow[t]{2}{*}{35.50417} & \multirow[t]{2}{*}{12.59528} & & \multirow[t]{2}{*}{ Sanctuary of Madonna di Porto Salvo } & 07/07/2015 & 4 \\
\hline & & & & & 29/10/2015 & 6 \\
\hline & 35.50064 & 12.60110 & & Medusa Hotel (garden) & $27 / 10 / 2015$ & 1 \\
\hline & 35.50500 & 12.61765 & & Costa House Resort (horse stable) & $30 / 10 / 2015$ & 1 \\
\hline \multirow[t]{12}{*}{ Pantelleria } & 36.75917 & 11.98788 & BG & Farm & $14 / 10 / 2015$ & 0 \\
\hline & \multirow[t]{2}{*}{36.82745} & \multirow[t]{2}{*}{11.93605} & & \multirow[t]{2}{*}{ Kennel } & $15 / 10 / 2015$ & 0 \\
\hline & & & & & 20/10/2015 & 0 \\
\hline & 36.76099 & 11.99949 & & Private residence (garden) & 19/10/2015 & 0 \\
\hline & 36.81558 & 11.98921 & & Private residence (garden) & 19/10/2015 & 4 \\
\hline & 36.81931 & 11.98613 & & Private residence (garden) & 19/10/2015 & 1 \\
\hline & 36.82761 & 11.94484 & & Private residence (garden) & 20/10/2015 & 5 \\
\hline & 36.83435 & 11.95353 & & Private residence (garden) & 20/10/2015 & 4 \\
\hline & 36.83112 & 11.94082 & & La Nicchia Restaurant & 20/10/2015 & 2 \\
\hline & 36.81593 & 11.98892 & A & Lake Specchio di Venere & $13 / 10 / 2015$ & 1 \\
\hline & 36.76088 & 11.98635 & & Farm & $14 / 10 / 2015$ & 1 \\
\hline & 36.76108 & 11.98576 & & Farm & $14 / 10 / 2015$ & 1 \\
\hline Linosa & 35.86167 & 12.86577 & A & Private residence (garden) & 28/10/2015 & 1 \\
\hline
\end{tabular}

sites) do not sustain abundant Ae. albopictus populations, they did not, however, prevent the arrival and spread of this invasive mosquito, mainly found in proximity to human settlements. On Lampedusa, the western side is flat and almost completely desert and the isolated residential houses have underground tanks for water storage. The eastern part of the island, where the port and the village are situated, is steadily supplied with water for domestic use and watering, and a wide variety of small and medium water containers, suitable as larval breeding sites, were found. In particular, the highest mosquito densities were found in shaded and cool 
Table 2 Placement of ovitraps and numbers of eggs collected on the islands of Lampedusa and Pantelleria, with the respective identification number (ID), georeference, sampling area, entomological survey and number of Aedes albopictus eggs found (L: ovitrap lost)

\begin{tabular}{|c|c|c|c|c|c|c|}
\hline Island & ID & Latitude (N) & Longitude (E) & Sampling area & Sampling period ${ }^{a}$ & No. of eggs \\
\hline \multirow[t]{16}{*}{ Lampedusa } & $01 \mathrm{~L}$ & 35.50639 & 12.59556 & Cupola Bianca Resort (garden) & $I+\|$ & 683 \\
\hline & \multirow[t]{2}{*}{$02 \mathrm{~L}$} & \multirow[t]{2}{*}{35.51048} & \multirow[t]{2}{*}{12.61708} & \multirow[t]{2}{*}{ Supermarket forecourt } & $1+\|$ & 20 \\
\hline & & & & & V & 0 \\
\hline & $03 \mathrm{~L}$ & 35.51046 & 12.61695 & Fruit shop (outside) & $\mid+\|$ & 3 \\
\hline & \multirow[t]{2}{*}{$04 \mathrm{~L}$} & \multirow[t]{2}{*}{35.50293} & \multirow[t]{2}{*}{12.60349} & \multirow[t]{2}{*}{ L'Aragosta Restaurant (veranda) } & $1+\|$ & 37 \\
\hline & & & & & V & 0 \\
\hline & \multirow[t]{2}{*}{$05 \mathrm{~L}$} & \multirow[t]{2}{*}{35.50417} & \multirow[t]{2}{*}{12.59528} & \multirow[t]{2}{*}{ Sanctuary of Madonna di Porto Salvo } & $1+\|$ & 331 \\
\hline & & & & & V & 0 \\
\hline & $06 \mathrm{~L}$ & 35.50500 & 12.61806 & Costa House Resort (garden) & $1+\|$ & 65 \\
\hline & \multirow[t]{2}{*}{$07 \mathrm{~L}$} & \multirow[t]{2}{*}{35.50333} & \multirow[t]{2}{*}{12.62083} & \multirow[t]{2}{*}{ New Cemetery } & $1+\|$ & 85 \\
\hline & & & & & V & 0 \\
\hline & $08 \mathrm{~L}$ & 35.50195 & 12.60667 & Medical Centre & $\mid+\|$ & 400 \\
\hline & $09 \mathrm{~L}$ & 35.51167 & 12.60194 & Immigrant Reception Center & $\mid+\|$ & 67 \\
\hline & $10 \mathrm{~L}$ & 35.50083 & 12.61984 & Airport & $1+\|$ & 79 \\
\hline & $11 \mathrm{~L}$ & 35.50333 & 12.62083 & Old Cemetery & $1+\|$ & 5 \\
\hline & $12 \mathrm{~L}$ & 35.50064 & 12.60110 & Hotel Medusa (garden) & V & 12 \\
\hline \multirow[t]{21}{*}{ Pantelleria } & $01 \mathrm{P}$ & 36.83011 & 11.93442 & Cemetery of Pantelleria & $I I I+I V$ & 22 \\
\hline & $02 \mathrm{P}$ & 36.83011 & 11.93442 & Cemetery of Pantelleria & $I I I+I V$ & 0 \\
\hline & 03P & 36.80377 & 12.03238 & Cemetery of Khamma & $I I I+I V$ & L \\
\hline & 04P & 36.75905 & 11.97651 & Cemetery of Scauri & $I I I+I V$ & 0 \\
\hline & 05P & 36.83469 & 11.94465 & Hospital (car park) & $I I I+I V$ & 39 \\
\hline & 06P & 36.76088 & 11.98635 & Farm & $I I I+I V$ & 0 \\
\hline & 07P & 36.80854 & 11.99058 & Farm & $I I I+I V$ & L \\
\hline & $08 \mathrm{P}$ & 36.78975 & 11.97964 & Farm & $I I I+I V$ & 31 \\
\hline & 09P & 36.79397 & 12.03099 & Farm & $I I I+I V$ & 51 \\
\hline & $10 P$ & 36.75917 & 11.98788 & Farm & $I I I+I V$ & 0 \\
\hline & $11 \mathrm{P}$ & 36.82595 & 11.94125 & Veterinary office & $I I I+I V$ & 0 \\
\hline & $12 \mathrm{P}$ & 36.81445 & 11.97672 & Farm & $I I I+I V$ & 0 \\
\hline & $13 \mathrm{P}$ & 36.82745 & 11.93605 & Kennel & $I I I+I V$ & 0 \\
\hline & $14 \mathrm{P}$ & 36.83066 & 11.93982 & Castiglione Restaurant (veranda) & $I I I+I V$ & 9 \\
\hline & $15 P$ & 36.76099 & 11.99949 & Private residence (garden) & $I I I+I V$ & 0 \\
\hline & $16 \mathrm{P}$ & 36.79576 & 11.95997 & Basile's winery & $I I I+I V$ & 31 \\
\hline & $17 P$ & 36.81558 & 11.98921 & Private residence (garden) & $I I I+I V$ & 19 \\
\hline & $18 \mathrm{P}$ & 36.81931 & 11.98613 & Private residence (garden) & $I I I+I V$ & 12 \\
\hline & $19 P$ & 36.82761 & 11.94484 & Private residence (garden) & $I I I+I V$ & 0 \\
\hline & $20 P$ & 36.83435 & 11.95353 & Private residence (garden) & $I I I+I V$ & 0 \\
\hline & $21 \mathrm{P}$ & 36.83112 & 11.94082 & La Nicchia Mare Restaurant (veranda) & $I I I+I V$ & 0 \\
\hline
\end{tabular}

aEntomological survey period: I: 6-9 July 2015; II: 14-18 July 2015; III: 12-16 October 2015; IV: 19-22 October 2015; V: 27-30 October 2015

places, such as the Sanctuary of Madonna di Porto Salvo that is close to an area with several caves, and at the cemetery where a few of the flower pots were colonised by larvae of Ae. albopictus, along with larvae of Culex pipiens. The survey in late October confirmed the occurrence of Ae. albopictus, although at a lower density. Due to limitations imposed by the ferry schedules and the inability to load large equipment, the ISS team visited Linosa over a few hours and no traps were positioned. Nevertheless, the inspections carried out in the small touristic village and in some isolated cottages allowed us to find Ae. albopictus on the island. Orography, climate 
Table 3 Potential man-made receptacles containing water during entomological visits on the islands of Pantelleria, Linosa and Lampedusa

\begin{tabular}{|c|c|c|c|c|}
\hline \multirow[t]{2}{*}{ Type of larval breeding site } & Lampedusa & Linosa & Pantelleria & Total \\
\hline & Pos/Neg & Pos/Neg & Pos/Neg & Pos/Neg \\
\hline Flower vase & $4 / 25$ & $1 / 15$ & $2 / 50$ & $7 / 90$ \\
\hline Plastic jerry can & $0 / 0$ & $0 / 3$ & $0 / 0$ & $0 / 3$ \\
\hline Bucket & $0 / 3$ & $1 / 2$ & $1 / 0$ & $2 / 5$ \\
\hline Wheelie dustbin & $0 / 0$ & $0 / 0$ & $0 / 1$ & $0 / 1$ \\
\hline Plastic tank & 0/0 & $0 / 0$ & $1 / 1$ & $1 / 1$ \\
\hline Cooking pot & $0 / 0$ & $0 / 3$ & $0 / 0$ & $0 / 3$ \\
\hline Dog bowl & $0 / 2$ & $0 / 0$ & $1 / 1$ & $1 / 3$ \\
\hline Animal trough & $0 / 3$ & $0 / 0$ & $0 / 0$ & $0 / 3$ \\
\hline Brick-tank for rainwater storage & $0 / 3$ & $0 / 2$ & $0 / 2$ & $0 / 7$ \\
\hline Manhole & $0 / 0$ & $0 / 0$ & $1 / 1$ & $1 / 1$ \\
\hline Water pit & $0 / 0$ & $0 / 0$ & $0 / 1$ & $0 / 1$ \\
\hline Well & $0 / 1$ & $0 / 0$ & $0 / 0$ & $0 / 1$ \\
\hline Total & $4 / 37$ & $2 / 25$ & $6 / 57$ & $12 / 119$ \\
\hline
\end{tabular}

Abbreviations: Pos/Neg, no. of positive/no. of negative larval breeding sites for immature stages of Ae. albopictus

and vegetation make Pantelleria the most suitable island to host stable Ae. albopictus populations in a large part of its territory. The mosquito was found in several places, though limiting factors, like the strong wind and the fact that the surveys took place late in the season, prevented us from detecting high densities.

\section{Conclusion}

For the first time Ae albopictus was recorded on Lampedusa, Linosa and Pantelleria, where no mosquito surveillance or control programmes are currently implemented. In the light of the presence of this competent vector of important mosquito-borne disease pathogens and the emergency due to the migrant people arriving from Africa and the Middle East, preparedness strategies should be planned on these islands by (i) acquiring further entomological data to monitor the Ae. albopictus spread and density and by taking the appropriate control measures, in particular at places at risk of the introduction of pathogens like the migrant reception centre, (ii) implementing a surveillance activity in points of entry (ports and airports) to warn of the introduction of other invasive mosquitoes like Aedes aegypti, and (iii) identifying priorities for immediate action and long term needs.

\section{Acknowledgments}

We would like to thank all the local Authorities and the inhabitants of the Lampedusa, Linosa and Pantelleria islands for their kind hospitality, full support and precious collaboration, pivotal in this study. The authors are grateful to $\mathrm{L}$. Gradoni for helpful suggestions and for reviewing the manuscript. A big thanks also to Lesley Mills for proof-reading. Finally, we are grateful to the anonymous reviewers for their valuable comments.

\section{Funding}

This study was supported by VectorNet and its funding agencies ECDC and EFSA (contract number OC/EFSA/AHAW/2013/02). FS was partially funded by the European Commission Framework Program Seven Award "InfraVec" (project number 228421), and by Elanco Animal Health (project number BIOIT140021). The funders had no role in study design, data collection and analysis, decision to publish, or preparation of the manuscript.

\section{Availability of data and materials}

The data generated and the material used during the current study are available from the corresponding author upon reasonable request.

\section{Authors' contributions}

$M D L, L T, F S, D B, S D A, A S, F A, F L R$ and SDS carried out sample collections and contributed to obtaining the results. MDL, LT, FS, DB, DT, SC, EC, W, FSC, RR and AT participated in the study design and critically reviewed the manuscript. MDL drafted the manuscript with the contribution of LT, FS, DB, W, FSC, RR and AT. All authors read and approved the final manuscript.

\section{Ethics approval and consent to participate}

Landing catches were carried out according to the Good Practice of Clinical Trials in Italy (Decree 211, June 24, 2003, Official Gazette of August 9, 2003), also taking into account the International Ethical Guidelines for Biomedical Research Involving Human Subjects and for Epidemiological Studies, as developed by the Council for International Organizations of Medical Science (www.cioms.ch).

\section{Consent for publication}

Not applicable.

\section{Competing interests}

The authors declare that they have no competing interests.

\section{Publisher's Note}

Springer Nature remains neutral with regard to jurisdictional claims in published maps and institutional affiliations.

\section{Author details}

'Department of Infectious Diseases, Unit of Vectorborne Diseases, Istituto Superiore di Sanità, Rome, Italy. ${ }^{2}$ Department of Veterinary Prevention, Unit of Animal Health Service, ASP Trapani, Pantelleria, Italy. ${ }^{3}$ Istituto Zooprofilattico Sperimentale della Sicilia, Laboratory of Entomology and Environmental Vectors Control, Palermo, Italy. ${ }^{4}$ City Council of Pantelleria, 
Pantelleria, Italy. ${ }^{5}$ Freelance Veterinarian, Lampedusa, Italy. ${ }^{6}$ City Council of Lampedusa and Linosa, Linosa, Italy. ${ }^{7}$ Avia-GIS, Risschotlei 33, 2980 Zoersel, Belgium. ${ }^{8}$ Francis Schaffner Consultancy, Riehen, Switzerland. ${ }^{9}$ Switzerland \& Institute of Parasitology, University of Zurich, Zurich, Switzerland.

\section{Received: 10 May 2017 Accepted: 19 October 2017}

Published online: 02 November 2017

\section{References}

1. Global Invasive Species Database. Invasive Species Specialist Group (ISSG). 2009. http://www.issg.org/database/species/ecology.asp?si=109\&fr=1\&sts= sss\&lang=EN. Accessed 12 Jun 2016.

2. Reiter P, Sprenger D. The used tire trade: a mechanism for the worldwide dispersal of container breeding mosquitoes. J Am Mosq Control Assoc. 1987:3:494-501.

3. Knudsen AB. Global distribution and continuing spread of Aedes albopictus. Parassitologia. 1995;37:91-7.

4. Madon MB, Mulla MS, Shaw MW, Kluh S, Hazelrigg JE. Introduction of Aedes albopictus (Skuse) in southern California and potential for its establishment. J Vector Ecol. 2002:27:149-54

5. Scholte EJ, Dijkstra E, Blok H, De Vries A, Takken W, Hofhuis A, et al. Accidental importation of the mosquito Aedes albopictus into the Netherlands: a survey of mosquito distribution and the presence of dengue virus. Med Vet Entomol 2008;22:352-358.

6. Medlock JM, Hansford KM, Schaffner F, Versteirt V, Hendrickx G, Zeller H, et al. A review of the invasive mosquitoes in Europe: ecology, public health risks, and control options. Vector Borne Zoonotic Dis. 2012;12:435-47.

7. Kraemer MUG, Sinka MEK, Duda A, Mylne AQN, Shearer FM, Barker CM, et al. The global distribution of the arbovirus vectors Aedes aegypti and Ae. albopictus. elife. 2015;4:e08347.

8. Medlock JM, Vaux AG, Cull B, Schaffner F, Gillingham E, Pfluger V, et al Detection of the invasive mosquito species Aedes albopictus in southern England. Lancet Infect Dis. 2017:17:140.

9. Adhami J, Murati N. Prani e mushkonjës Aedes albopictus në shqipëri. Rev Mjekesore. 1987;:1:13-6.

10. Sabatini A, Raineri V, Trovato G, Coluzzi M. Aedes albopictus in Italia e possibile diffusione della specie nell'area mediterranea. Parassitologia. 1990:32:30|-4.

11. Dalla Pozza GL, Majori G. First record of Aedes albopictus establishment in Italy. J Am Mosq Control Assoc. 1992;8:318-20.

12. Romi R, Toma L, Severini F, Di Luca M. Twenty years of presence of Aedes albopictus in Italy: from the annoying pest mosquito to the real diseases vector. Eur Infect Dis. 2008;2:98-101.

13. Gratz NG. Critical review of the vector status of Aedes albopictus. Med Vet Entomol. 2004;18:215-227.

14. Rezza G, Nicoletti L, Angelini R, Romi R, Finarelli AC, Panning M, et al. Infection with chikungunya virus in Italy: an outbreak in a temperate region. Lancet. 2007;370:1840-6.

15. La Ruche $G$, Souarès $Y$, Armengaud $A$, Peloux-Petiot F, Delaunay $P$, Desprès $P$, et al. First two autochthonous dengue virus infections in metropolitan France, September 2010. Euro Surveill. 2010;15:19676.

16. Schmidt-Chanasit J, Haditsch M, Schoneberg I, Gunther S, Stark K, Frank C. Dengue virus infection in a traveller returning from Croatia to Germany. Euro Surveill. 2010;15:19677.

17. Gjenero-Margan I, Aleraj B, Krajcar D, Lesnikar V, Klobučar A, Pem-Novosel I, et al. Autochthonous dengue fever in Croatia, August-September 2010. Euro Surveill. 2011;16:19805

18. Marchand E, Prat C, Jeannin C, Lafont E, Bergmann T, Flusin O, et al. Autochthonous case of dengue in France, October 2013. Euro Surveill. 2013;18:20661.

19. Delisle E, Rousseau C, Broche B, Leparc-Goffart I, L'Ambert G, Cochet A, et al. Chikungunya outbreak in Montpellier, France, September to October 2014. Euro Surveill. 2015;20:21108.

20. Chouin-Carneiro T, Vega-Rua A, Vazeille M, Yebakima A, Girod R, Goindin D, et al. Differential susceptibilities of Aedes aegypti and Aedes albopictus from the Americas to Zika virus. PLoS Negl Trop Dis. 2016;10:e0004543.

21. Di Luca M, Severini F, Toma L, Boccolini D, Romi R, Remoli ME, et al. Experimental studies of susceptibility of Italian Aedes albopictus to Zika virus. Euro Surveill. 2016:21:30223.

22. Heitmann A, Jansen S, Lühken R, Leggewie M, Badusche M, Pluskota B, et al. Experimental transmission of Zika virus by mosquitoes from central Europe. Euro Surveill. 2017;22:30437.
23. Schaffner F, Bellini R, Petrić D, Scholte E-J, Zeller H, Marrama RL. Development of guidelines for the surveillance of invasive mosquitoes in Europe. Parasit Vectors. 2013;6:209.

24. Miquel M, Del Río R, Borrás D, Barceló C, Paredes-Esquivel C, Lucientes, J, et al. First detection of Aedes albopictus (Diptera: Culicidae) in the Balearic Islands (Spain). J Eur Mosq Control Ass. 2013;31:8-11.

25. Gatt P, Deeming JC, Schaffner F. First record of Aedes (Stegomyia) albopictus (Skuse) (Diptera:Culicidae) in Malta. Eur Mosq Bull. 2009;27:56-64.

26. European Centre for Disease Prevention and Control (ECDC) 2012 Guidelines for the surveillance of invasive mosquitoes in Europe. Stockholm; 2012. doi https://doi.org/10.2900/61134.

27. Severini F, Toma L, Di Luca M, Romi R. Le zanzare italiane: generalità e identificazione degli adulti (Diptera: Culicidae). Fragmenta Entomol 2009:41. 213-372.

28. Romi R, Sabatinelli G, Pontuale G. Le zanzare italiane: generalità e identificazione degli stadi preimaginali (Diptera, Culicidae). Fragmenta Entomol. 1997;29(Suppl):1-141.

29. Schaffner F, Angel G, Geoffroy B, Hervy JP, Rhaiem A, Brunhes J. The mosquitoes of Europe. An identification and training programme [CD-ROM] Montpellier: IRD Éditions \& EID Méditerrannée; 2001.

30. Prestileo T, Cassarà G, Di Lorenzo F, Sanfilippo A, Dalle Nogare ER. Infectious diseases and health in the migrant people: experience from Lampedusa 2011. Infez Med. 2013;21:21-8.

31. Pasta L, Mesa Suero LA, Farinella EM, Marchese G, Serravalle D, D'Amico N, et al. Le cause di ricovero in ospedale dei migranti approdati a Lampedusa da gennaio 2011 a giugno 2014. Epidemiol Prev. 2015:39:55-8.

32. Buhagiar JA. A second record of Aedes (Stegomyia) albopictus (Diptera: Culicidae) in Malta. Eur Mosq Bull. 2009;27:65-7.

33. Barceló C, Bengoa M, Monerris M, Molina R, Delacour-Estrella S, Lucientes J, et al. First record of Aedes albopictus (Skuse, 1894) (Diptera; Culicidae) from Ibiza (Balearic Islands; Spain). J Eur Mosq Control Ass. 2015;33:1-4.

34. Bengoa M, Delacour-Estrella S, Barceló C, Paredes-Esquivel C, Leza M, Lucientes J, et al. First record of Aedes albopictus (Skuse, 1894) (Diptera; Culicidae) from Minorca (Balearic Islands, Spain). J Eur Mosq Control Ass. 2016;34:5-9.

35. Torina A, Sole M, Longo R, Romi R. First monitoring of Aedes albopictus (Diptera: Culicidae) in Palermo, Sicily. Parassitologia. 2006:48:166.

36. Cuffaro S, Sole M, Bosco G, Torina A, Caracappa S. Monitoring of Aedes albopictus (Diptera: Culicidae) in Agrigento Province, Sicily. Parassitologia. 2008;50:145.

37. European Centre for Disease Prevention and Control (ECDC) 2017. http:// ecdc.europa.eu/en/healthtopics/vectors/vector-maps/Pages/NBORNET_maps. aspx. Accessed 26 Apr 2017.

\section{Submit your next manuscript to BioMed Central and we will help you at every step:}

- We accept pre-submission inquiries

- Our selector tool helps you to find the most relevant journal

- We provide round the clock customer support

- Convenient online submission

- Thorough peer review

- Inclusion in PubMed and all major indexing services

- Maximum visibility for your research

Submit your manuscript at www.biomedcentral.com/submit 